\title{
Environmental Management Program (EMP) for Radiological Hazards, of Granite Fines Waste as A Naturally Occurring Radioactive Material (NORM)
}

\author{
A.A. Bakhit ${ }^{\mathrm{a}}$, Hany A. Shousha ${ }^{\mathrm{b}}$, Zeinab. Yousef $^{\mathrm{c}}$. \\ a Nuclear Materials Authority (NMA), Egypt. \\ b National Institute for Standards (NIS), Egypt. \\ c Faculty of Women for arts, Science and Education, Ain Shams University, Egypt \\ * Corresponding author. Tel.: +201141669595.
}

E-mail addresses: dr_bakr@NMA.org.eg.

\begin{abstract}
Shaq Al - Thu'ban industrial cluster, East Cairo is the largest granite industrial agglomeration in Egypt as well as the fourth world ranked granite industrial zone. It poses the most imminent hazard to the surrounding environment and workers and the neighboring residential communities due to the huge amounts of waste resulted during the processing of the granite.

Many of the previous studies in the world dealt with raising the added value of granite fines waste (GFW), such as use in the manufacture of concrete industry, ceramics industry, mortar industry, pigment-based paints industry, agriculture and forestry etc., to raise the economic feasibility of (GFW).

The current study examined the radiological hazards as a naturally occurring radioactive material (NORM) in (GFW) and proposed an environmental management program (EMP) that takes into consideration the requirements of ISO: 14040 and the high radiation background in those wastes.

Results shows that ${ }^{238} \mathrm{U},{ }^{226} \mathrm{Ra},{ }^{232} \mathrm{Th}$, and ${ }^{40} \mathrm{~K}$ concentrations in samples ranged from $58.48 \pm 4$ to $79.35 \pm 5 \mathrm{~Bq} \mathrm{~kg}^{-1}, 57.65 \pm 3$ to $78.01 \pm 6.3 \mathrm{~Bq} \mathrm{~kg}^{-1}, 66.5 \pm 5.6$ to $87.58 \pm 7.2$ $\mathrm{Bq} \mathrm{kg} \mathrm{kg}^{-1}$ and $845.73 \pm 71.74$ to $925.7 \pm 69.8 \mathrm{~Bq} \mathrm{~kg}^{-1}$ respectively. The average of the absorbed dose rate, the annual effective dose and the gamma index was around a mean value of $116.72 \pm 10 \mathrm{nGy} \mathrm{h}^{-1}, 0.57 \pm 0.2 \mathrm{mSv} \mathrm{y}^{-1}$ and $1.84 \pm 0.2$, respectively. Investigated waste samples can also be used in various industries to raise the added value and economic feasibility while setting the controls set by the proposed (EMP).
\end{abstract}

\section{Keywords:}

Environmental Management Program, Granite Fines Waste, Naturally Occurring, Radioactive Material, Life cycle assessment 


\section{Introduction}

According to UNEP (United Nations Environment Program) life cycle assessment (LCA) is one of the environment management techniques of assessing environmental aspects and potential environmental impacts during the whole lifetime of a product, from raw materials acquisition, through production and use to disposal [1].

The assessment can be conducted for both the product and its functions, and it is treated as a cradle-to-gate analysis. The main components of LCA are: the identification and quantitative assessment of the environmental loads, i.e, spent materials, energy, emissions and wastes introduced into the environment, an assessment of the potential environmental impacts of the loads and an evaluation of the potential ways of reducing them. The principal aspiration of LCA is to take into account all the product related factors having a bearing on the environment [2].

Among its other aims one can distinguish the evaluation of different firms in the same line of business or processes resulting in identical or nearly identical products [3].

Several major stages are distinguished in the structure of LCA. The first stage, i.e. goal and range definition, is key since it decides the choice of an assessment technique and its degree of detail. The defined goal and the intended use of the results determine the limits of the model and the choice of qualitative-quantitative parameters [4].

An essential element of any LCA analysis is the definition of the aim of the investigation, and the target group to which the results will be presented. It should be noted that LCA is a decision aiding tool and that the interested parties are engaged in the decision process. Besides stating the reasons for undertaking an LCA analysis one should specify its type (a comparative/non-comparative analysis). The goal and the use of results are the main determinants of the structure of a life cycle assessment.

The range of investigation is defined mainly by characterizing the range and type of data to be acquired and the limits of the system. Then the life cycle stages to be covered by the investigation, i.e. the system's breadth and its level of advancement. In addition, the geographical, time and technological extent of an LCA study is defined and the kinds of environmental effects and the methods of estimating them are indicated, whereby the basis for classification and characterization is obtained [5].

During the last decades, the granite industry in Egypt has significantly grown. Shaq Al - Thu'ban area, East Cairo, is the largest granite industrial cluster in Egypt and the fourth world-industrial zone. Large quantities of (GFW) [6] are generated as by products during the cutting and polishing processes of the blocks, Figs 1 and 2. As the waste is not discarded properly, this practice imposes tangible effects on the ecosystem (i.e. the physical, chemical and biological, radiological components of the environment) as well as imposing pollution threats to the neighboring residential communities Figs 3 and 4. This situation is challenging and should be successfully resolved. Accordingly, a research plan has been designed by the authors to characterize the radiological hazards in granite processing fines waste and proposed (EMP), and evaluating their feasibility for incorporation as alternative raw material in some building material industries. 
The first Part of the research studied radiological hazards resulted from naturally occurring radioactive material (NORM) in (GFW), the second part of the research proposed (EMP)

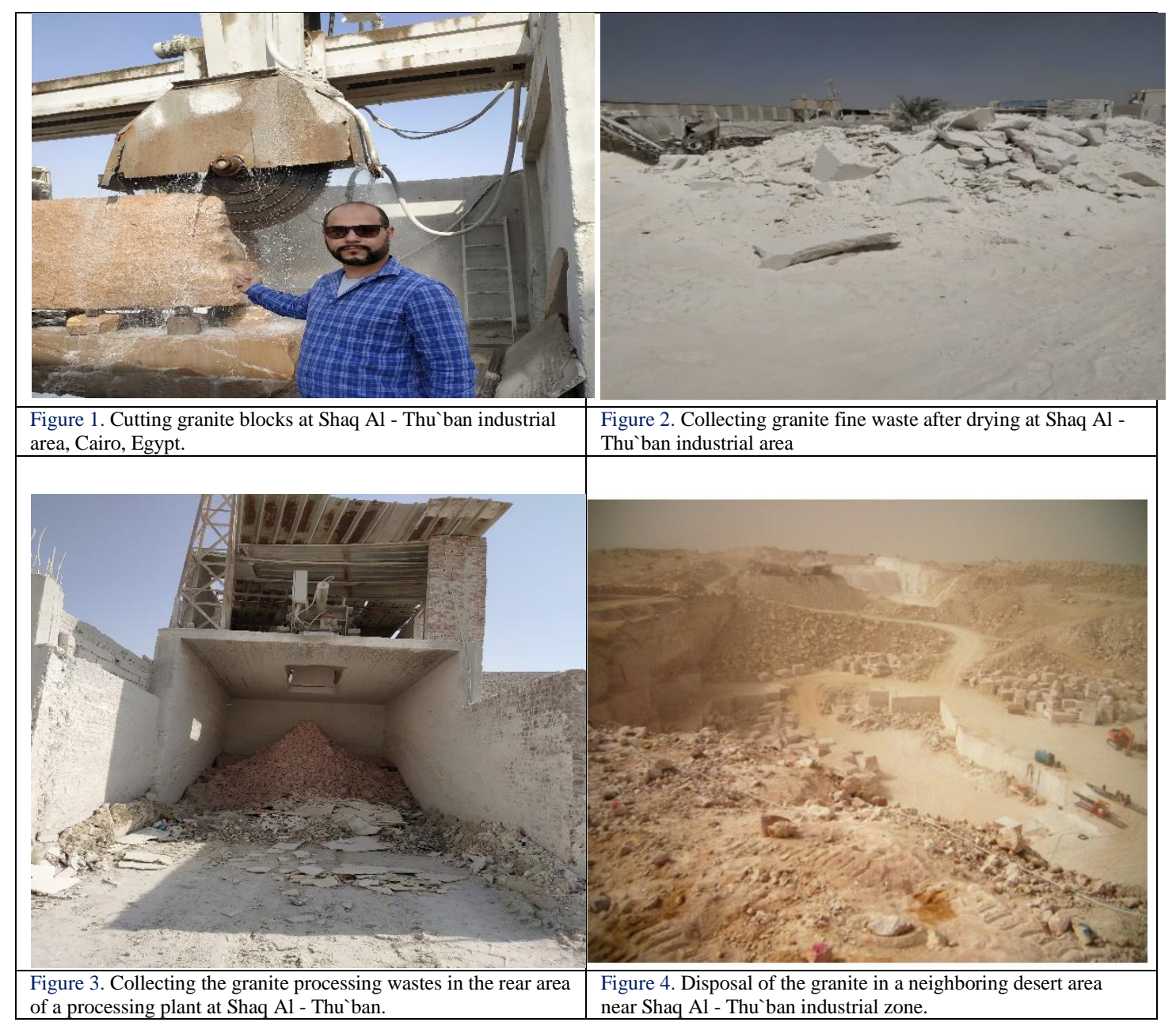

\section{Materials and Methods}

\section{Sampling and Sample Preparation}

Three samples of (GFW) were collected, from inside the wells used to collect the slab and polish in the factory, from three factories for slab and polish in Shaq Al Thu 'ban area, Egypt to measure the specific radioactivity of ${ }^{238} \mathrm{U},{ }^{232} \mathrm{Th}$ and ${ }^{40} \mathrm{~K}$. The samples were transferred to polyethylene Marinelli beakers and sealed and left for at least 4 weeks to reach secular equilibrium between radium and thorium, and their progenies [6].

\section{Gamma-Ray Spectroscopic Technique}

Activity measurements have been performed using gamma ray spectrometer system, which consists of ORTEC hyper pure germanium (HPGe) model No. GEM15190 coaxial type detector with serial No.27-P-1876A recommended operating bias, 
voltage is $-3 \mathrm{KV}$. The detector used has crystal diameter $49.3 \mathrm{~mm}$ and length $47.1 \mathrm{~mm}$. The HPGe detector has a FWHM of $0.9 \mathrm{KeV}$ at $122 \mathrm{KeV}$ gamma transition of ${ }^{57} \mathrm{Co}$ and $1.9 \mathrm{KeV}$ at the $1332.5 \mathrm{KeV}$ of ${ }^{60} \mathrm{Co}$ gamma transition. The $\gamma$-ray spectrometer energy calibration was performed using ${ }^{60} \mathrm{Co},{ }^{226} \mathrm{Ra}$ and ${ }^{241} \mathrm{Am}$ point sources. The detector was surrounded by a special heavy lead shield of $10 \mathrm{~cm}$ thickness with inside dimensions of $28 \mathrm{~cm}$ diameter and $40 \mathrm{~cm}$ height.

${ }^{238} \mathrm{U}$ was determined from the gamma rays emitted by its daughter products [7] ${ }^{234} \mathrm{Th}$ and ${ }^{234 \mathrm{~m}} \mathrm{~Pa}$ activities determined from the 63.3 and $1001 \mathrm{KeV}$ photo peaks, respectively, ${ }^{214} \mathrm{Bi}(609.3,1120.3,1238.1,1377.7$ and $1764.5 \mathrm{KeV}),{ }^{214} \mathrm{~Pb}(295.1$ and $352.0 \mathrm{KeV}$ ). The specific activity of ${ }^{226} \mathrm{Ra}$ was measured using the $186.1 \mathrm{KeV}$ from its own gamma-ray (after the subtraction of the $185.7 \mathrm{KeV}$ of ${ }^{235} \mathrm{U}$ ). The specific activity of ${ }^{232} \mathrm{Th}$ was measured using the 338.4, 911.2 and $968.9 \mathrm{KeV}$ lines from ${ }^{228} \mathrm{Ac}$ and 583 $\mathrm{KeV}$ peak from ${ }^{208} \mathrm{Tl}$, and ${ }^{40} \mathrm{~K}$ was measured using $1460.8 \mathrm{KeV}$ peak.

In order to determine the background contribution due to naturally occurring radionuclides in the environment around the detector, an empty polyethylene Marinelli beaker was counted with the same geometrical conditions as the sample. The measurement time for both activity and background measurement was $(83979,90 \mathrm{sec})$. The background spectra were used to correct the net gamma ray peak areas for the studied isotopes.

\section{Results and discussion}

The activity concentration of ${ }^{226} \mathrm{Ra},{ }^{238} \mathrm{U},{ }^{232} \mathrm{Th}$ and ${ }^{40} \mathrm{~K}\left(\mathrm{~Bq} \mathrm{~kg}^{-1}\right)$ in samples under investigation are listed in table (1). It is clear that the activity concentrations of the studied samples are higher than the permissible levels for ${ }^{226} \mathrm{Ra},{ }^{238} \mathrm{U},{ }^{232} \mathrm{Th}$ and ${ }^{40} \mathrm{~K}$ which are 33, 32, 45 and $412 \mathrm{~Bq} \mathrm{~kg}^{-1}$ respectively according to UNSCEAR 2010 [8]. The ratios of ${ }^{232} \mathrm{Th} /{ }^{238} \mathrm{U}$ are less than the Clark's value (3.5) in all samples, which indicates that these locations are enriched in uranium. Also, the activity ratios ${ }^{226} \mathrm{Ra} /{ }^{238} \mathrm{U}$ were calculated for investigated samples. All samples show equilibrium $(0.98-0.99)$ between ${ }^{226} \mathrm{Ra}$ and ${ }^{238} \mathrm{U}$.

Table (1) Activity concentration of ${ }^{226} \mathrm{Ra},{ }^{238} \mathrm{U},{ }^{232} \mathrm{Th}$ and ${ }^{40} \mathrm{~K}$ in $\mathrm{Bq} \mathrm{kg}^{-1}$ with ${ }^{232} \mathrm{Th} /{ }^{238} \mathrm{U}$ and ${ }^{226} \mathrm{Ra} /{ }^{238} \mathrm{U}$ ratios of the (GFW) samples.

\begin{tabular}{|c|c|c|c|c|c|c|}
\hline Samples & ${ }^{\mathbf{2 2}} \mathbf{R a}$ & ${ }^{\mathbf{2 3 8}} \mathbf{U}$ & ${ }^{\mathbf{2 3 2}} \mathbf{T h}$ & ${ }^{\mathbf{4}} \mathbf{K}$ & ${ }^{\mathbf{2 3}^{23}} \mathbf{T h} /{ }^{\mathbf{2 3 8}} \mathbf{U}$ & ${ }^{\mathbf{2 2}^{26} \mathbf{R a} /{ }^{\mathbf{3 8}} \mathbf{U}}$ \\
\hline Mix 1 & 78.01 & 79.35 & 76.82 & 924.67 & 0.97 & 0.98 \\
\hline Mix 2 & 57.65 & 58.48 & 66.50 & 925.70 & 1.14 & 0.99 \\
\hline Mix 3 & 74.16 & 74.86 & 87.58 & 845.73 & 1.17 & 0.99 \\
\hline
\end{tabular}

\section{Radiological hazard indices}

\section{Radium equivalent activity (Raeq)}

Since the distribution of the natural radionuclides are not uniform in the samples under analysis, a radiological index called radium equivalent $\left(\mathrm{Ra}_{\mathrm{eq}}\right)$ activity has been 
defined to estimate the radiation risk associated with these radionuclides. This index is calculated by the equation [14]

$$
\mathrm{Ra}_{\mathrm{eq}}=\mathrm{C}_{\mathrm{Ra}}+\left(\mathrm{C}_{\mathrm{Th}} * 1.43\right)+\left(\mathrm{C}_{\mathrm{K}} * 0.077\right)
$$

where $\mathrm{C}_{\mathrm{Ra}}, \mathrm{C}_{\mathrm{Th}}$ and $\mathrm{C}_{\mathrm{K}}$ are the activity concentration of ${ }^{238} \mathrm{U},{ }^{232} \mathrm{Th},{ }^{40} \mathrm{~K}$ in $\mathrm{Bq} \mathrm{kg}^{-}$ ${ }^{1}$, respectively. As shown in figure (5), the $\mathrm{Ra}_{\mathrm{eq}}$ values for investigated samples varied from 265.21 to $224.85 \mathrm{~Bq} \mathrm{~kg}^{-1}$ which is less than recommended value of $370 \mathrm{~Bq} \mathrm{~kg}^{-1}$ (19). This common index is widely used as a radiological hazard index. It is convenient for comparing the specific activities of materials containing different concentrations of ${ }^{238} \mathrm{U},{ }^{232} \mathrm{Th},{ }^{40} \mathrm{~K}$.

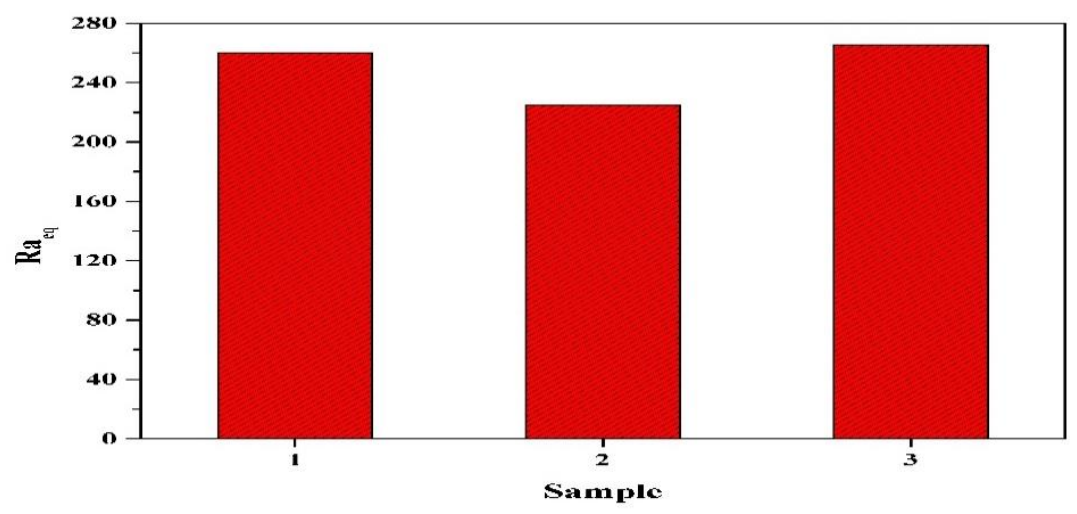

Figure 5. Radium equivalent activity $\left(\mathrm{Ra}_{\mathrm{eq}}\right)$.

\section{External and internal hazard index}

The external hazard index $\left(\mathrm{H}_{\mathrm{ex}}\right)$ due to the emitted gamma rays of the samples is calculated and examined according to the equation, [15]

$$
\mathrm{H}_{\mathrm{ex}}=\mathrm{C}_{\mathrm{Ra}} / 370+\mathrm{C}_{\mathrm{Th}} / 259+\mathrm{C}_{\mathrm{K}} / 4810 \leq 1,
$$

where $\mathrm{C}_{\mathrm{Ra}}, \mathrm{C}_{\mathrm{Th}}$ and $\mathrm{C}_{\mathrm{K}}$ are the activity concentration of ${ }^{238} \mathrm{U},{ }^{232} \mathrm{Th},{ }^{40} \mathrm{~K}$ in $\mathrm{Bq} \mathrm{kg}^{-1}$, respectively. The calculated external hazard values are between 0.61 and 0.72 . The mean value of the external hazard index (0.68) is less than the recommended value as shown in figure (6).

Also, radon and its short-lived products are hazardous to the respiratory system. The internal exposure to radon and its daughter progenies is quantified by the internal hazard index $\left(\mathrm{H}_{\mathrm{in}}\right)$. It is given by equation, [16]

$$
\mathrm{H}_{\text {in }}=\mathrm{C}_{\mathrm{Ra}} / 185+\mathrm{C}_{\mathrm{Th}} / 259+\mathrm{C}_{\mathrm{K}} / 4810 \leq 1,
$$

The calculated external hazard values are between 0.77 and 0.92 . The mean value of the external hazard index (0.87) is less than the recommended value as shown in figure (6). The values of $\mathrm{H}_{\mathrm{ex}}$ and $\mathrm{H}_{\text {in }}$ must be less than unity for the radiation hazard to be negligible. 


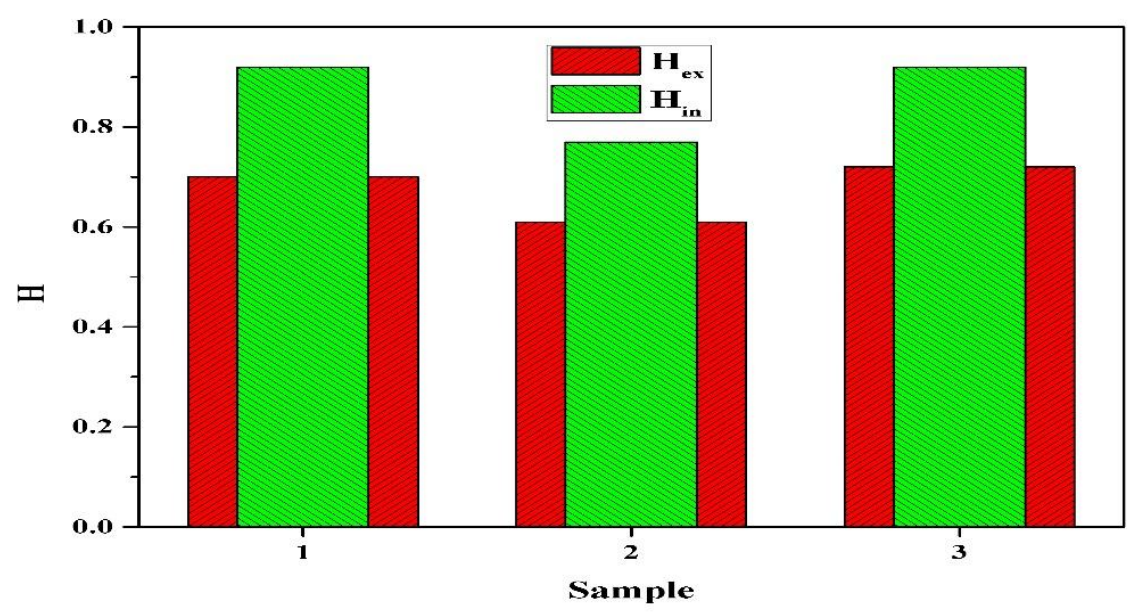

Figure 6. External hazard index $\left(\mathrm{H}_{\mathrm{ex}}\right)$

\section{Representative level index}

This index is a gamma radiation representative level index $\left(\mathrm{I}_{\gamma}\right)$ which is used to estimate the level of gamma radiation associated with different concentrations of some specific radionuclides to estimate the associated level of gamma radiation hazard for investigated samples; it is given by the equation [17]

$$
\mathrm{I}_{\gamma}=\mathrm{C}_{\mathrm{Ra}} / 150+\mathrm{C}_{\mathrm{Th}} / 100+\mathrm{C}_{\mathrm{K}} / 1500,
$$

where $\mathrm{C}_{\mathrm{Ra}}, \mathrm{C}_{\mathrm{Th}}$ and $\mathrm{C}_{\mathrm{K}}$ are the activity concentration of ${ }^{238} \mathrm{U},{ }^{232} \mathrm{Th},{ }^{40} \mathrm{~K}$ in $\mathrm{Bq} \mathrm{kg}^{-1}$, respectively. The mean value of radioactivity level index $\left(\mathrm{I}_{\gamma}\right)$ is found $0.92 \mathrm{~Bq} \mathrm{~kg}^{-1}$ which is higher than recommended value $\leq 0.5$ which corresponds to annual effective dose less than or equal to $0.3 \mathrm{mSv} \mathrm{y}^{-1}$ when the material is used in bulk quantity.

\section{Estimation of $\gamma$-radiation dose}

The absorbed gamma dose rates (D) in air at $1 \mathrm{~m}$ above the ground surface were calculated by using equation, (D) is expressed in $\left(\mathrm{nGy} \mathrm{h}^{-1}\right)$ [18]

$$
\mathrm{D}=0.462 * \mathrm{C}_{\mathrm{U}}+0.602 * \mathrm{C}_{\mathrm{Th}}+0.0417 * \mathrm{C}_{\mathrm{K}}
$$

where $\mathrm{C}_{\mathrm{Ra}}, \mathrm{C}_{\mathrm{Th}}$ and $\mathrm{C}_{\mathrm{K}}$ are the activity concentration of ${ }^{238} \mathrm{U},{ }^{232} \mathrm{Th},{ }^{40} \mathrm{~K}$ in $\mathrm{Bq} \mathrm{kg}^{-1}$, respectively.

\section{Annual effective dose equivalent (AEDE)}

The indoor $\left(E_{\text {in }}\right)$ and outdoor $\left(E_{\text {out }}\right)$ AEDE were estimated from the dose rate $(D)$, time of stay indoor and outdoor using occupancy factor (OF $=80 \%$ and $20 \%$ of 8760 $\mathrm{h}$ in a year respectively) and the conversion factor $\left(\mathrm{CF}=0.7 \mathrm{~Sv} \cdot \mathrm{Gy}^{-1}\right)$ to convert the absorbed dose in air to effective dose. In present study, the $\mathrm{E}_{\text {in }}$ and $\mathrm{E}_{\text {out }}$ was calculated using the following equations from UNSCEAR, 2010 [4]

$$
\begin{aligned}
\mathrm{E}_{\text {out }} & =\mathrm{D}_{\text {out }}\left(\mathrm{nGy} \mathrm{h}^{-1}\right) * 0.2 * 8760 \mathrm{~h} * 0.7\left(\mathrm{~Sv} \mathrm{~Gy}^{-1}\right) \\
\mathrm{E}_{\text {in }} & =\mathrm{D}_{\text {in }}\left(\mathrm{nGy} \mathrm{h}^{-1}\right) * 0.8 * 8760 \mathrm{~h} * 0.7\left(\mathrm{~Sv} . G y^{-1}\right)
\end{aligned}
$$

The estimated results for (D) and the corresponding (E) in and out are shown in figures (7) and (8). The estimated (D), $\left(E_{\text {out }}\right)$ and $\left(E_{\text {in }}\right)$ values for all the studied samples ranged from 105.78 to $122.75\left(\mathrm{nGy} \mathrm{h}^{-1}\right), 0.1$ to $0.12\left(\mathrm{mSv} \mathrm{yr}^{-1}\right)$ and 0.52 to $0.6\left(\mathrm{mSv} \mathrm{yr}^{-}\right.$ $\left.{ }^{1}\right)$ respectively. The estimated mean value of (D) in the studied samples is $116.72 \mathrm{nGy}$ $\mathrm{h}^{-1}$ which is higher than world average $80 \mathrm{nGy} \mathrm{h}^{-1}(18)$. However, the estimated mean 
value of indoor and outdoor annual effective dose equivalent was 0.57 and 0.11 $\mathrm{mSv} \mathrm{yr}^{-1}$ which is slightly higher than the permissible limit 0.41 and $0.07 \mathrm{mSv}_{\mathrm{yr}}{ }^{-1}$ respectively UNSCEAR, 2008.

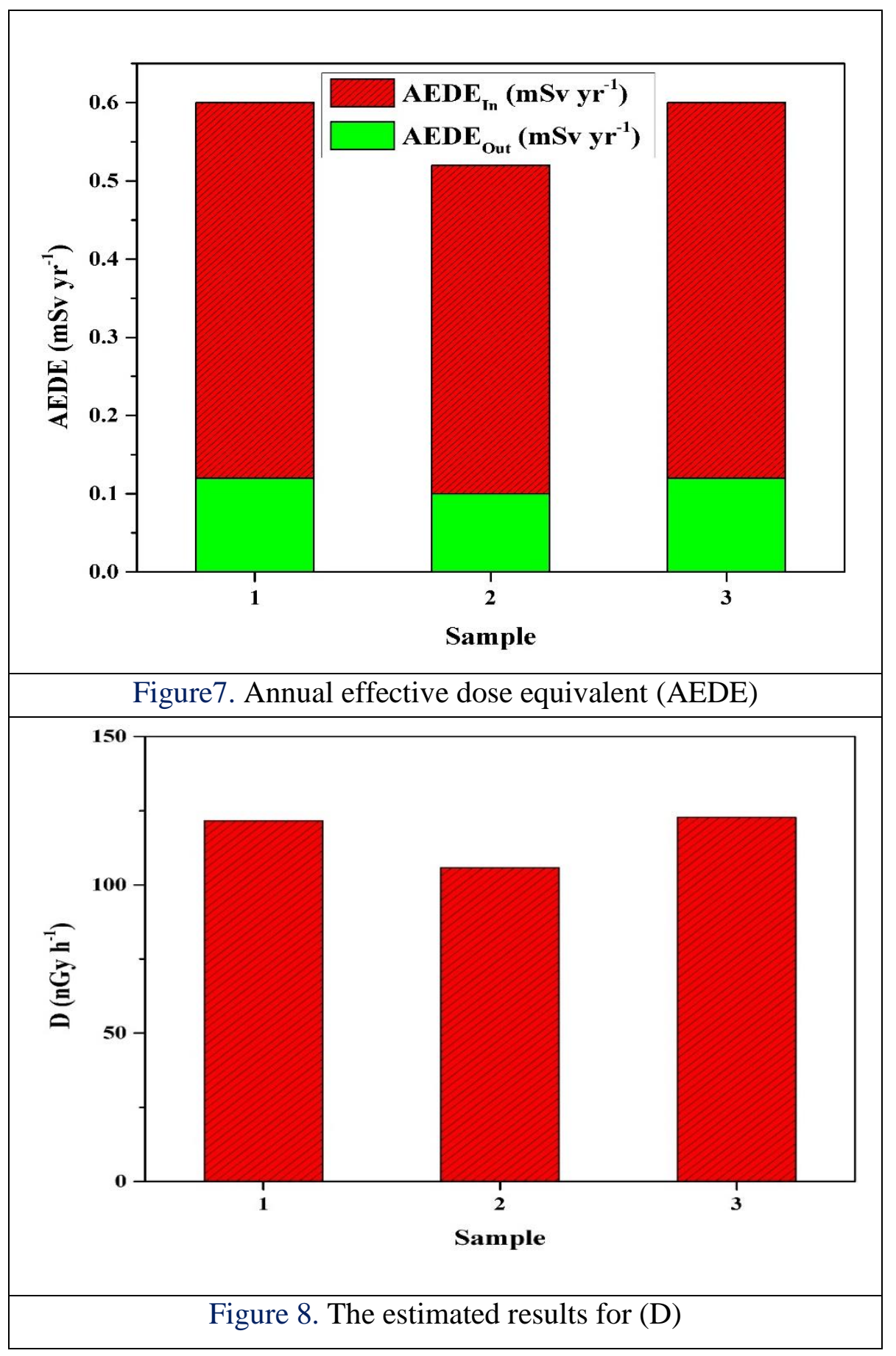

Compares natural radioactivity concentrations reported for granite rock obtained in other published data with those obtained in this study, the radioactivity in investigated granite samples varied from one country to another. These values are not the representative values for those mentioned countries but for the regions from where 
the samples were collected. The radionuclides concentration for the granite samples in present study were higher than most reported countries and within the same range with data published in Turkey.

Table (2) Comparison of radionuclides concentrations $\left(\mathrm{Bq} \mathrm{kg}^{-1}\right)$ in granite rock obtained in published data with those obtained from this study.

\begin{tabular}{|c|c|c|c|c|}
\hline Country & ${ }^{\mathbf{2 2 6}} \mathbf{R a}$ & ${ }^{\mathbf{2 3 2}} \mathbf{T h}$ & ${ }^{\mathbf{4 0}} \mathbf{K}$ & Reference \\
\hline $\begin{array}{c}\text { Brazil } \\
\text { (Commercial granite) }\end{array}$ & $5.2-169$ & $4.5-448.5$ & $190-2028$ & {$[10]$} \\
\hline $\begin{array}{c}\text { China } \\
\text { (Commercial granite) }\end{array}$ & $14.5-204.7$ & $16.7-186.7$ & $185.7-1745.6$ & {$[11]$} \\
\hline Cyprus & $1-588$ & $1-906$ & $50-1606$ & {$[12]$} \\
\hline Greece & $1.6-170$ & $30-354$ & $49-1592$ & {$[13]$} \\
\hline Turkey & $43-651$ & $51-351$ & $418-1618$ & {$[14]$} \\
\hline Egypt & $57.65-78.01$ & $66.5-87.58$ & $845.73-925.7$ & Present study \\
\hline
\end{tabular}

The proposed (EMP) of the (GFW) uses: (table 3)

(LCA) is one of the environment management techniques (Figure 9) of assessing aspects and potential environmental impacts during the whole lifetime of a product, from raw materials acquisition, through production and use to disposal.

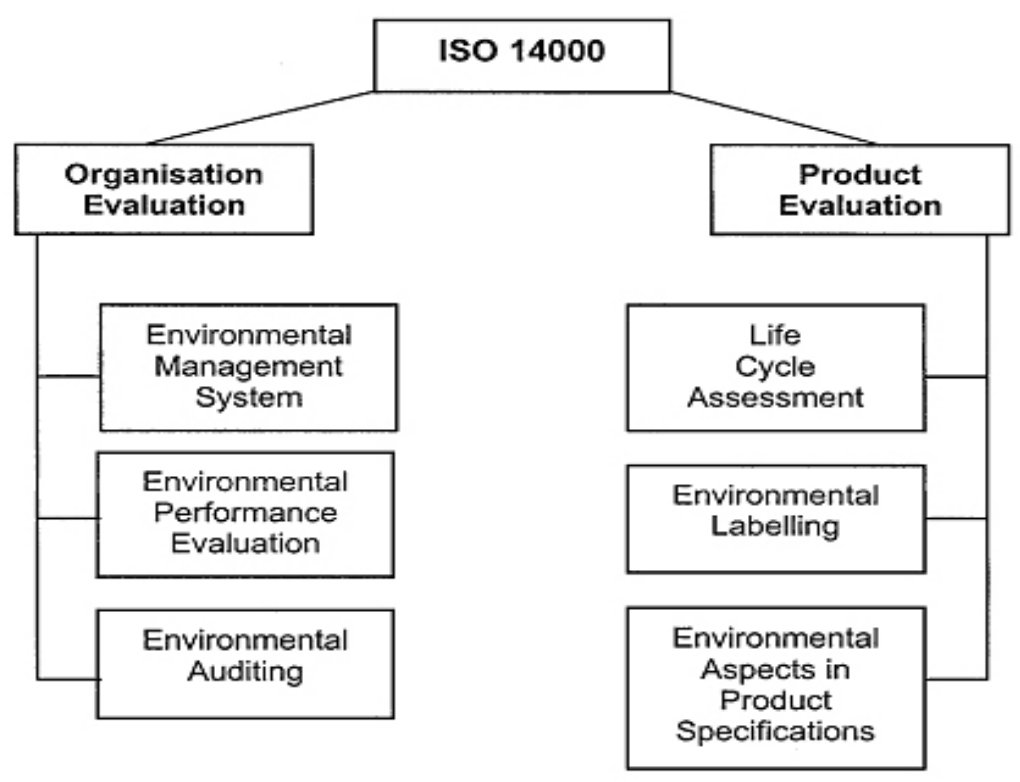

Figure 9. ISO 14040:14044 as a part of 14000 ISO family

The environmental performance of granite production is analyzed using the environmental footprint indicators defined by the European Recommendation [20] to measure and communicate the life cycle environmental performance of products and organizations. The European Commission's product environmental footprint (PEF) 
guide [21] specifies a set of 14 indicators based on the evaluation of the best impact assessment methods included [22]. The environmental indicators are: acidification, A (mol H eq.), ecotoxicity for aquatic freshwater, EAFW (CTUe e Comparative Toxic Unit for ecosystems), Freshwater eutrophication, FE (kg P eq.), human toxicity e cancer effects, HTc (CTUh e Comparative Toxic Unit for humans), human toxicity e noncancer effects, HTn-c (CTUh), Ionizing radiation e human health effects, IR (kg U235 eq.), IPCC global warming, GW (kg CO2 eq.), marine eutrophication, $\mathrm{ME}$ (kg N eq.), ozone depletion, OD (kg CFC-11 eq.), respiratory inorganics, RI (PM 2.5 eq.), photochemical ozone formation, POF (kg NMVOC eq.), resource depletion e fossil and mineral, $\mathrm{RD}$ (kg Sb eq.), terrestrial eutrophication, TE (mol N eq.), and water depletion, in (Table 3) The proposed (EMP) of the (GFW):

First step: Life Cycle assessment (LCA) ISO: 14044 (Fig.9).

Second step: Survey of potential alternatives for promoting the material recovery of (GWF) to use as a raw materials (Fig10).

Third step: Risk assessment considering radiological hazards and ISO and IAEA requirement and the (EMP) (table 3).

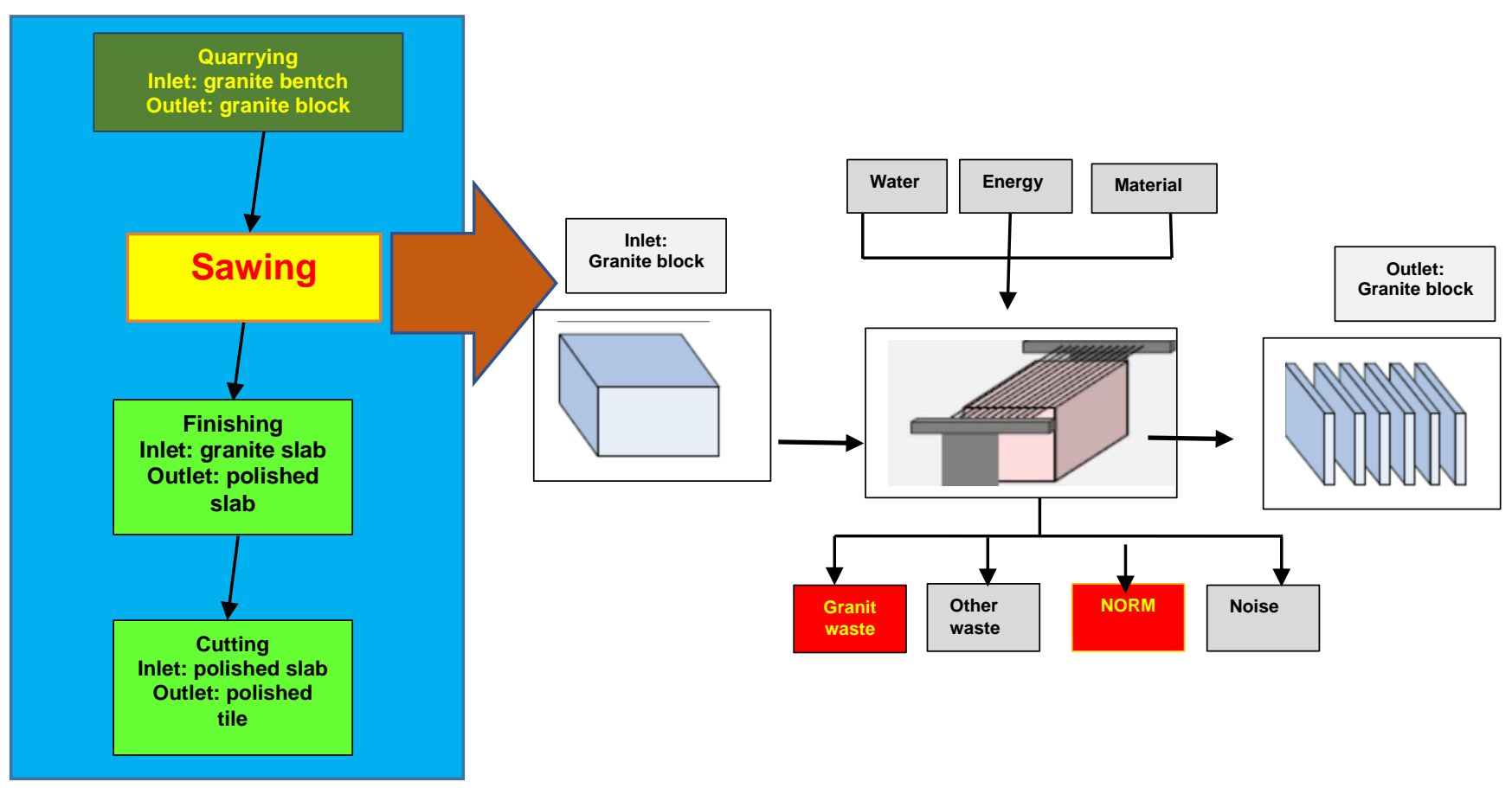

Fig (10) Life Cycle Assessment 
ISSN 2537_0715

IJSRSD (2020): Volume 3, Issue 3, December 2020

Received: November 2020, Accepted: December 2020

International Journal of Scientific

Research and Sustainable Development

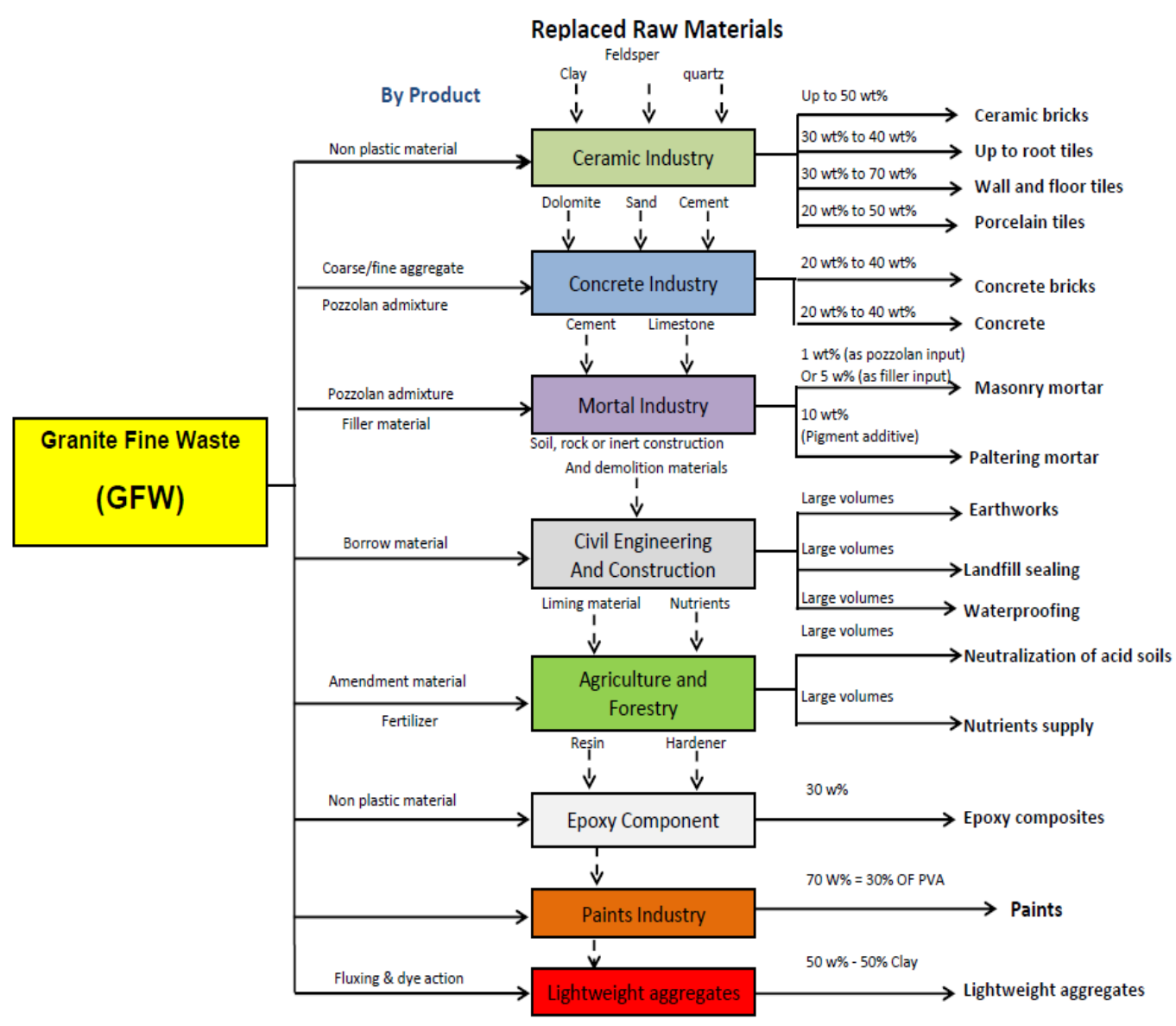

Fig. 11. Survey of potential alternatives for promoting the material recovery of (GFW) to use as a raw materials

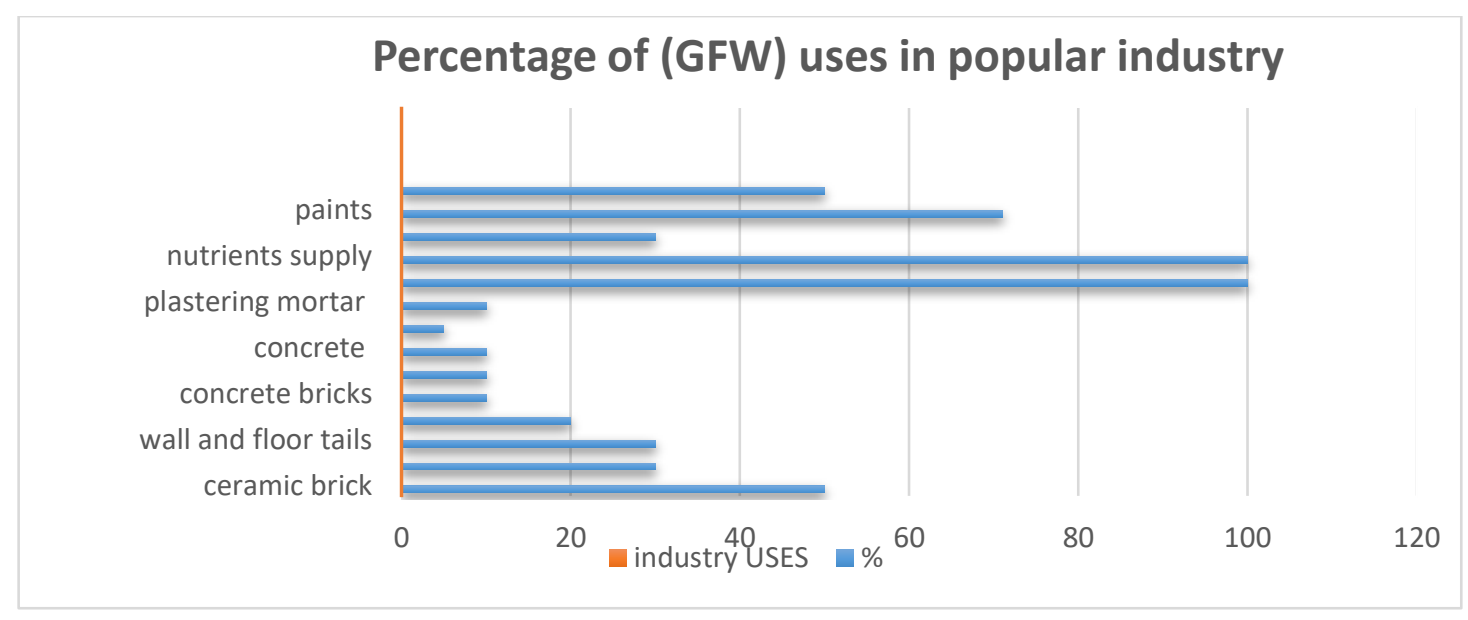

Fig (12) Percentage of potential alternatives for promoting the material recovery of (GFW) to use as a raw materials 


\section{Conclusion}

Table 3: The proposed and REC (EMP)

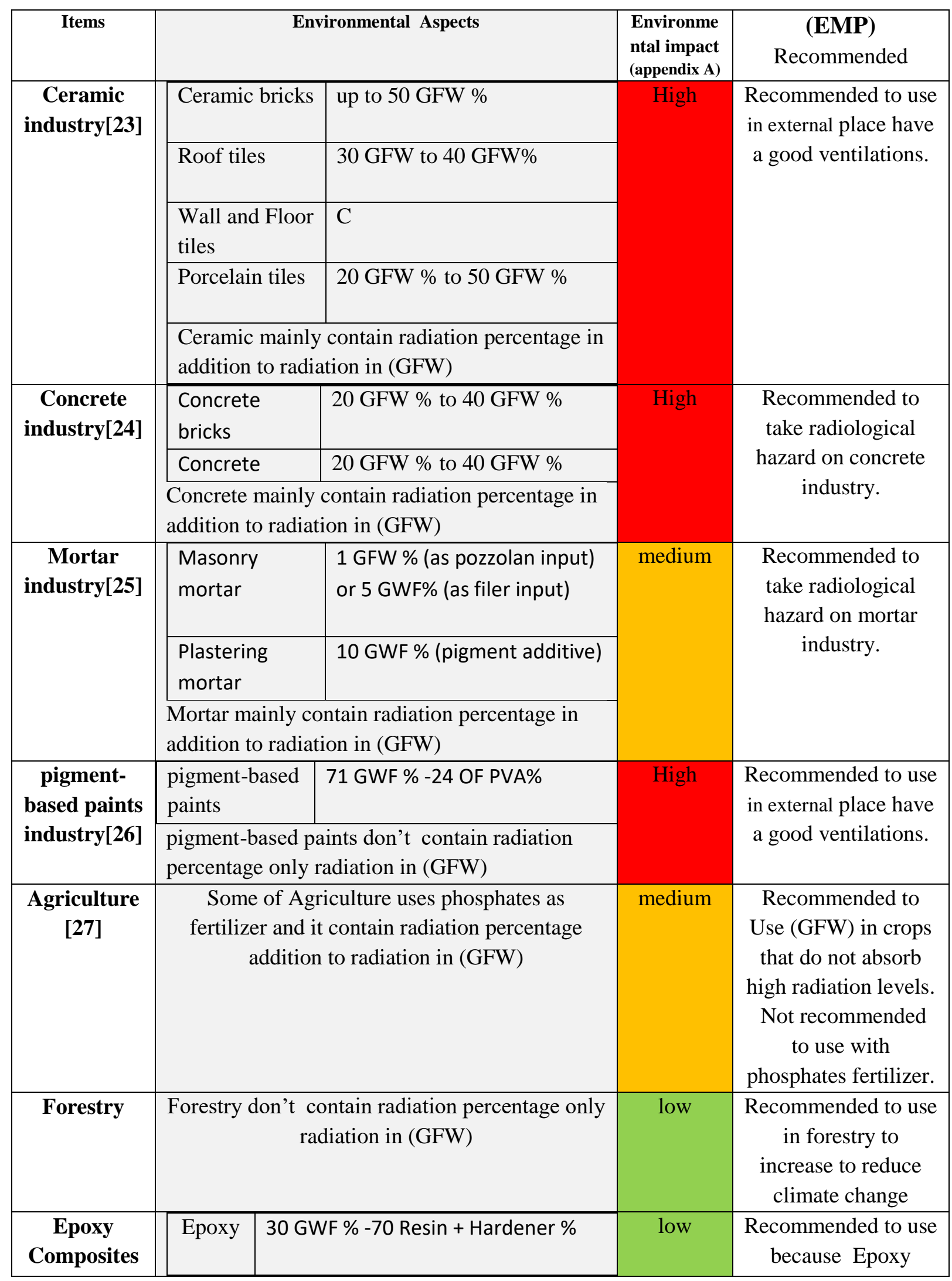




\begin{tabular}{|c|c|c|c|c|}
\hline$[28]$ & $\begin{array}{l}\text { Epoxy Compos } \\
\text { percentage only }\end{array}$ & $\begin{array}{l}\text { es don't contain radiation } \\
\text { adiation in (GFW) }\end{array}$ & & $\begin{array}{l}\text { Composites don't } \\
\text { contain radiation } \\
\text { percentage only } \\
\text { radiation in (GFW) }\end{array}$ \\
\hline $\begin{array}{c}\text { Lightweight } \\
\text { aggregates }\end{array}$ & $\begin{array}{c}\text { Lightweight } \\
\text { aggregates }\end{array}$ & 50GWF \% -50 Clay \% & \multirow[t]{2}{*}{ High } & \multirow{2}{*}{$\begin{array}{l}\text { Recommended to use } \\
\text { in external place have } \\
\text { a good ventilations. }\end{array}$} \\
\hline & \multicolumn{2}{|c|}{$\begin{array}{c}\text { Lightweight aggregates don't contain radiation } \\
\text { percentage only radiation in }(\mathrm{GFW})\end{array}$} & & \\
\hline $\begin{array}{c}\text { Waste } \\
\text { storage }\end{array}$ & \multicolumn{2}{|c|}{ The (GFW) have a (NORM) } & High & $\begin{array}{l}\text { The government } \\
\text { must create a legal } \\
\text { obligation to safely } \\
\text { storage these wastes } \\
\text { and classify them as } \\
\text { hazardous waste }\end{array}$ \\
\hline $\begin{array}{c}\text { Waste } \\
\text { handling }\end{array}$ & \multicolumn{2}{|c|}{ The (GFW) have a (NORM) } & High & $\begin{array}{l}\text { The government } \\
\text { must create a legal } \\
\text { obligation to safely } \\
\text { handle these wastes } \\
\text { and classify them as } \\
\text { hazardous waste }\end{array}$ \\
\hline $\begin{array}{c}\text { Waste } \\
\text { disposal }\end{array}$ & \multicolumn{2}{|c|}{ The (GFW) have a (NORM) } & High & $\begin{array}{c}\text { The government } \\
\text { must create a legal } \\
\text { obligation to safely } \\
\text { disposal these wastes } \\
\text { and classify them as } \\
\text { hazardous waste }\end{array}$ \\
\hline $\begin{array}{c}\text { Monitoring } \\
\text { area }\end{array}$ & \multicolumn{2}{|c|}{ The (GFW) have a (NORM) } & High & $\begin{array}{c}\text { Necessity of } \\
\text { operating fixed } \\
\text { radiological } \\
\text { monitoring stations } \\
\text { in the area of Shaq } \\
\text { Al - Thu 'ban. }\end{array}$ \\
\hline $\begin{array}{l}\text { Internationa } \\
\text { I standards }\end{array}$ & \multicolumn{2}{|c|}{ The (GFW) have a (NORM) } & medium & $\begin{array}{l}\text { Factories should } \\
\text { adopt with } \\
\text { International } \\
\text { standards. }\end{array}$ \\
\hline
\end{tabular}




\section{Standard methods referred:}

1- ISO: 14040 International Standard Organization, Environmental Management - Life Cycle Assessment.

2- ISO: 14044 International Standard Organization, Environmental Management - Life Cycle Assessment.

3- ISO: 14001 International Standard Organization, Environmental Management System Requirements with Guidance for Use.

4- (PEF) The European Commission's product environmental footprint guide.

5- (UNSCEAR) United Nations Scientific Committee on the Effects of Atomic Radiation

6- ILCD Handbook, International Reference Life Cycle Data System [30].

\section{Conflicts of interest}

None.

\section{Appendix A.}

Risk assessment in this study make by https://www.machin-safetyspecialists.com/riskassessment/free-spreadsheet/. 


\section{References}

1- ISO 14044:2009, Environmental Management - Life Cycle Assessment Requirements and Guidelines. International Standard 14040: 2009. International Organization for Standardization, Geneva.

2- Kulczycka, J., Góralczyk, K., Koneczny, P., Przewrocki, P. and Wasik, A., 2001. Environmental life cycle assessment (LCA) using new environmental management

3- Czaplicka, K., and Bojarskn-Kraus, M., 2002. Application of life cycle assessment in the mining industry. A method of estimating eco-indicators for unit processes (in Polish). Scientific papers of GiG. Mining and Environment. Quarterly, 2: 5-16.

4- PN-EN ISO 14044:2009, Environmental management - Life cycle assessment Principles and structure (in Polish).

5- Lesiuk, A., Oleszczuk, P. and Kuśmierz, M., 2012. The application of the LCA technique in the environmental assessment of products, technologies and waste management, Adsorbents and catalysts. Selected technologies and the environment (in Polish). Rzeszów: Nauka dla gospodarki, 2: 453-466.

6- Lokeshwari Ma,, K.S Jagadis, 2016. Eco-Friendly use of Granite Fines Waste in Building Blocks International Conference on Solid Waste Management, 5IconSWM 2015, journal of Procedia Environmental Sciences 35, p 620.

7- Fawzia Ahmad, and Hany A. Shousha "Measurement of natural radioactivity in commercial granites and glazing stones from Aswan area, Egypt" Isotope and Radiation Research, Vol. 37, No. 7, pp 1749 - 1763, 2005.

8- R.A. Sutherland, E. de Jong. Statistical analysis of gamma-emitting radionuclide concentrations for three fields in southern Saskatchewan, Canada. Health Phys 58 (1990) 417.

9- Sources and Effects of Ionizing Radiation. Report to General Assembly with Scientific Annexes (New York, United Nations Scientific Committee on the Effect of Atomic Radiation, 2010).

10- M. Tufail et al. Natural radioactivity from the building materials used in Islamabad and Rawalpindi, Pakistan. Science of the Total Environmental 121 (1992) 283.

11- Xinwei L (2004) Natural radioactivity in some building materials and by-products of Shaanxi, China. Journal of Radio analytical and Nuclear Chemistry, 262: 775777.

12- Hany A. Shousha "Radioactive analysis and radiological hazards in different types of Egyptian cement." Radiation Effects \& Defects in Solids, Vol. 161, No. 10, pp $615-627$, October 2006.

13- NEA Group (1979) Nuclear energy Agency, exposure to radiation from natural radioactivity in building materials, OECD, Paris.

14- United Nations Scientific Committee on the Effects of Atomic Radiation, (UNSCEAR) (2000) Report to General Assembly, with Scientific Annexes, Sources and Effects of Ionizing Radiation, United Nations, New York. 
15- Sources and Effects of Ionizing Radiation. Report to General Assembly with

Scientific Annexes (New York, United Nations Scientific Committee on the Effect of Atomic Radiation, 2010).

16- R. Anjos, R. Veiga, T. Soares, A. Santos, J. Aguiar, M. Frascac, J. Brage, D. Uzêda, L. Mangia, A. Facure, B. Mosquera, C. Carvalho, P. Gomes, "Natural radionuclide distribution in Brazilian commercial granites", Radiation Measurements 39, (2005) 245-253.

17- L. Xinwei, W. Lingqing, J. Xiaodan, , Y. Leipeng, and D. Gelian, "Specific activity and hazards of Archeozoic-Cambrian rock samples collected from the Weibei area of Shaanxi, China", Radiation Protection Dosimetry, 118 (3), (2006) 352-359.

18- M. Tzortzis, H. Tsertos, S. Christofides, and G. Christodoulides, "Gamma Radiation Measurements and Dose Rates in Commercially Used Natural Tiling Rocks (Granites)", Journal of Environmental Radioactivity, 70, (2003) 223-235.

19- C. Papastefanou, S. Stoulos, and M. Manolopoulou. "The radioactivity of building materials“, Journal of Radioanalytical and Nuclear Chemistry, 266 (3), (2005), 367 372.

20- Y. Orgun, N. Altınsoy, A. H. Gultekin, G. Karahan, and N. Celebi, Appllied Radiaiont and Isotopes, 63, (2005), 267-275.

21- European Commission, 2013a. Building the Single Market for Green Products Facilitating Better Information on the Environmental Performance of Products and Organizations. COM, 196 Final.

22- European Commission, 2013b. Commission recommendation on the use of common methods to measure and communicate the life cycle environmental performance of products and organizations (2013/179/EU). Off. J. Eur. Union 56 (L124).

23- Menezes, R.R., Neves, G.A., Ferreira, H.C., Lira, H.L., 2002. Recycling of granite industry waste from the northeast region of Brazil. Env. Manag. Health 13 (2), 134e141. http://dx.doi.org/10.1108/09566160210424527.

24- Narendra Kumar Sharma., Praveen Kumar., Sanjeev Kumar., Blessen Skariah Thomas., Ramesh Chandra Gupta. Properties of concrete containing polished granite waste as partial substitution of coarse aggregate. Construction and Building Materials 151 (2017) P.158.

25- Barrientos, V., Delgado, J., Navarro, V., Juncosa, R., Falcón, I., Vázquez, A., 2010. Characterization and geochemical geotechnical properties of granite sawdust produced by the dimension stone industry of O Porriño (Pontevedra, Spain). Q. J. Eng. Geol. Hydrogeol. 43, 141e155. http://dx.doi.org/10.1144/1470-9236/ 08-098. 26- Márcia Maria Salgado Lopes., Rita de Cássia Silva Sant'Ana Alvarenga., Leonardo Gonçalves Pedroti., José Carlos Lopes Ribeiro ., Anôr Fiorini de Carvalho., Fernando de Paula Cardoso., Beatryz Cardoso Mendes. Influence of the incorporation of granite waste on the hiding power and abrasion resistance of soil pigment-based paints. Construction and Building Materials 205 (2019) 463-474. 

granite powder as an amendment and fertilizer for acid soils. Chemosphere 61, 993e1002. http://dx.doi.org/10.1016/j.chemosphere.2005.03.010.

28- C Subhash., M Rama Krishna., M Sai Raj., B Harsha Sai., S Rama Raoa. Development of Granite Powder Reinforced Epoxy Composites. Materials Today: Proceedings 5 (2018) 13010-13014.

29- Abdel Monem Mohamed Soltan., Wolf-Achim Kahl ., Fawzia Abd EL-Raoof., Baher Abdel-Hamid El-Kaliouby., Mohamed Abdel-Kader Serry., Noha Ali AbdelKader. Lightweight aggregates from mixtures of granite wastes with clay.Journal of Cleaner Production 117 (2016) 139e149.

30- ILCD Handbook, 2010. General Guide for Life Cycle Assessment - Detailed Guidance. International Reference Life Cycle Data System. Institute for Environment and Sustainability, Joint Research Centre, European Commission. 